\title{
Melville and the question of American decolonization
}

\section{Citation}

Buell, Lawrence. 1992. Melville and the question of American decolonization. American Literature 64(2): 215-237.

\section{Published Version}

http://dx.doi.org/10.2307/2927833

\section{Permanent link}

http://nrs.harvard.edu/urn-3:HUL.InstRepos:2643654

\section{Terms of Use}

This article was downloaded from Harvard University's DASH repository, and is made available under the terms and conditions applicable to Other Posted Material, as set forth at http:// nrs.harvard.edu/urn-3:HUL.InstRepos:dash.current.terms-of-use\#LAA

\section{Share Your Story}

The Harvard community has made this article openly available.

Please share how this access benefits you. Submit a story.

Accessibility 


\section{Lawrence Melville and the Question of Buell American Decolonization}

$t$ is striking that the last great work of the so-called American Renaissance should have been a tale about the consequences of impressment, a tale that portrays the forcible absorption into an imperial or old world order of a protagonist who, as R. W. B. Lewis long ago pointed out, is transparently a kind of republican or new world representative (although nominally British). ${ }^{1}$ Melville's Billy Budd thus opens by obliquely reopening one of the greatest grievances that postrevolutionary America harbored against Britain, a grievance which helped precipitate the War of 1812, our "second war of independence." Billy's impressment story goes on to become an ambiguous parable of the rite of passage to cultural maturity, from a comparatively egalitarian "state-of-nature" community aboard the Rights of Man to the Bellipotent's more hierarchical and "advanced" society, dominated by a rule of law. Through the figure of Billy Budd, the notion of American difference is insinuated only to be preempted and repressed except as a kind of nostalgic afterglow.

The symbolic polarity between the two ships also hints at coming of age in a literary sense: Billy is translated from something like an oral culture, in which disputes get resolved through action, to the stage of print culture, where orality is forced underground (persisting in gossip and balladry) and disputes get resolved through discourse and by appeal to codified rules - a culture, furthermore, in which the presiding figure is directly aligned with a canonical text from the British poetic tradition, Andrew Marvell's “Upon Appleton House," which Melville quotes as follows:

This 'tis to have been from the first

In a domestic heaven nursed, 


\section{American Literature}

Under the discipline severe

Of Fairfax and the starry Vere. ${ }^{2}$

The "this" of the quatrain refers in the broadest sense to the whole estate but more specifically to Mary Fairfax's genteely constructed upbringing, which Marvell praises, although (as Melville perhaps knew) her prospects were almost as ominous as Billy Budd's-her marriage, as Raymond Williams puts it, being "that kind of political deal in which property and title were reconstituted." ${ }^{3}$ Mary and Billy, then, were each young innocents whose nurture within the pseudo-Eden of Vere's patriarchy proved baleful, not auspicious. Melville would doubtless also have noticed that the poet himself was in a position akin to theirs-less naive but still an inhabitant of that same domestic heaven, working within the patronage system both as tutor and as bard of the local manor.

With the hint supplied by this poem in mind, we can imagine the polarity of Billy Budd's two shipboard microcosms as reflecting not only upon issues of personal maturation, moral philosophy, and political values, but also upon the issue of American expression in the age of literary emergence and, more specifically, as inviting us to read Melville's last literary will and testament as a reminiscence about what happens when an American autodidact (such as the young ex-sailor Melville liked to picture himself as being) enters the arena of cosmopolitan culture. The young writer-like the young sailor-quickly finds that free expression is regulated and constrained by the world of "measured forms" for which Vere stands. This ultimately leads, in the mature writer, to a style of insinuation rather than direct statement.

Coming as it does so near the end of the nineteenth century and of Melville's life, Billy Budd is a dramatic instance of American literature dwelling upon the idea of transition to personal and cultural maturity long after personal and cultural maturity have supposedly been reached. As such it provides an image of American postcolonial anxiety. But it is only one of many such images in Melville's work, which differ mutually and to some extent clash. For example, in Redburn, the protagonist's innocence takes the form not of unlettered Adamism but of his internalization of his father's genteel Anglophilia. In Israel Potter, it takes the form of Israel's never grasping that the republican establishment is just as selfinterested, in its own way, as the imperial. In White-Jacket and Moby-Dick, innocence takes the form of not realizing at first how imperial forms persist in American enterprise. All of these and other such scenarios have 
to do with the theme of intellectual coming of age within contexts that either literally or metaphorically contrast America and Europe, but these individual contrasts and (even more) the totality of them become ironized and complicated to the point that the predictable opposition of republican virtue and imperial decadence becomes even more muddied than in Henry James. It is not so much the employment of the scenario, or even its repetition, as the inconsistency and muddying that is the definitive mark of what I'm calling postcolonial anxiety. ${ }^{4}$ This essay explores its sources and unfolding in Melville's life and work.

One obvious place to begin would be with the signs of cultural deference in the biographical record: for example, the pleasure Melville took during his 1849 trip to Britain in buying and reading English authors like DeQuincey, or his thawing out the frigidity of one London publisher, Edward Moxon, by conversing enthusiastically about Charles Lamb. ${ }^{5}$ These are two small indicators among many that it did not come naturally for Melville to think of himself simply and cleanly as an American man of letters, that he sought from the first to align himself with the larger Anglophone literary tradition rather than to classify himself (as Americanists do today) as an American writer-notwithstanding the famous dedication of Moby-Dick to Hawthorne and certain jingoistic remarks made in "Hawthorne and His Mosses" about supporting native authors for the sake of cultural nationalism. "Bartleby the Scrivener" is more Dickensian than Poe-esque, Moby-Dick at least as Shakespearean as Hawthornian; and The Confidence-Man owes at least as much to Swift, Fielding, and Sterne as it does to the American vernacular conning tradition.

Such biographical and intertextual evidence looks all the more important given the exigencies of Melville's position as literary professional during the formative years of his career. Recent scholarship on postcolonial writing in the various European languages has called attention to what might be called the "two audiences" phenomenon: namely, the issue of how postcolonial authors negotiate the problem of writing both for their countrymen and for the Western world audience on which commercial success in good part also depends. In a study of African writers' consciousness of audience based on personal interviews, the West African critic Phanuel Egejuru claims that African writers in European languages have been caught in the dilemma of having to serve as agents of cultural 
independence while remaining "dependent on the ex-masters' literary tradition, taste, and approval." ${ }^{7}$ Egejuru presses her point too judgmentally, overgeneralizing from her interviewees' responses and sometimes assuming the ideological co-optation she is supposedly trying to prove; but in her excess of zeal she identifies an important creative irritant, pertinent to the American as well as the African case.

Take for example this passage from one of the already canonical African Anglophone novels, Ngugi wa Thiong'o's Petals of Blood, an anatomy of neocolonial corruption and popular resistance in Kenya:

[T]here are many questions about our history which remain unanswered. Our present day historians, following on similar theories yarned out by defenders of imperialism, insist we only arrived here yesterday. Where went all the Kenyan people who used to trade with China, India, Arabia, long before Vasco da Gama came to the scene and on the strength of gunpowder ushered in an era of blood and terror and instability - an era that climaxed in the reign of imperialism over Kenya? . . . The story of this heroic resistance: who will sing it? Their struggles to defend their land, their wealth, their lives: who'll tell of it? ${ }^{8}$

This passage clearly tries to address two constituencies, each with its own interest: the audience for whom darkest Africa has no history (the position characterized and refuted in the second and third sentences) and the compatriot for whom the historicity is self-evident but needs an articulation that the passage seeks to encourage. The first audience is "European," the second "native"-categories, however, that refer more to attitudes than literal citizenship, since some Kenyan readers will have colonized minds and Ngugi does not wish to be trapped into localizing the honorable position of cultural insidership too much. So the passage creates a studiously amphibious "we": the "our" of "our history" means "Kenyan" or "African," but "our historians" could mean "Europeans"; the community of readers appealed to by the rhetorical questions might be as specific as "those leftist writers of Kenya who might undertake such a revisionist task" or as inclusive as "potentially sympathetic world opinion." For present purposes, it is less important to speculate further on what referent is intended when than simply to see the passage as an instance of rhetorical complexity forced upon the postcolonial writer by reason of the two audiences phenomenon, an enforcement that an able writer like Ngugi will turn into an aesthetic opportunity.

Students of nineteenth-century American literature tend to assume 
that American Renaissance texts were written for American readers, ${ }^{9}$ yet on reflection we know that that is no more accurate than the assumption that American authors read only American books. Clearly, the dream of reaching a bicontinental audience strongly influenced American writers, for reasons both of economics and prestige, from the dawn of national literary emergence with Washington Irving's Sketch-Book until well after the American book market had surpassed the British in the 1850s. The rhetoric of American Renaissance literature reflects this. To look for a moment at Irving's case, his essay on "English Writers on America" garnered praise on both sides of the Atlantic for the diplomatic suavity with which it mediated gently between British condescension and American hypersensitivity - which two topics the essay addresses seriatim. While continuing to underscore his own position as American and by implication the perceptual gap between the two audiences (Americans are always "we," the English "they"), Irving promotes rapprochement by a conciliatory citizen-of-the-world urbanity, diagnosing both partisans as self-victimized by silly prejudices that inhibit the recognition of their common bonds. This strategy wards off the intellectual oppressor at the cost (also, however, a potential benefit) of having to grant the provincialism of one's own cultural camp..$^{10}$

Melville, thirty-five years younger than Irving, is justly seen as carrying the cause of American literary independence further; yet he too was baptized into authorship in such a way as to be made equally conscious of the two audiences phenomenon, and he was at least as shrewd in developing a rhetorical repertoire to accommodate himself to it and exploit it. Not by mere chance was Irving one of the young Melville's backers among the publishers of London. Typee was a self-styled Yankee narrative got up, however, in a special effort to ingratiate itself with a British publisher and public and then remade so as to address a different problem of reception back home. The Preface, purporting to speak the "unvarnished truth," seems to have been designed to help market the book in Britain by appeasing both the publisher's and the public's demand for a factual narrative. In other words, if we read this great American author in chronological order, from stem to stern, we start with an essay that wasn't written for "us" but for British readers. Typee in fact remains throughout strongly Anglophilic; and the Appendix (on Hawaiian politics) is so egregiously pro-British (and as a consequence anti-American missionary) as to make Charles Anderson suppose it to have been written at least partly "to promote the sale of Typee in England." ${ }^{11}$ In America, this very accommodationism ran Melville into trouble. Leon Howard points 
out in the Historical Note to the Northwestern-Newberry Edition that whereas for British reviewers the vexing issue was veracity, for American reviewers the issue was Melville's censure of missionaries, which in combination with the mild eroticism of his Polynesian sketchery drove one evangelical reviewer to charge him with truckling to decadent European taste: "the work was made, not for America, but for a circle, and that not the highest, in London, where theatres, opera-dancers, and voluptuous prints have made such unblushing walks along the edge of modesty as are . . rather more admired than we hope they are among us." ${ }^{12}$

Melville responded to criticism of his impiety and salaciousness by both bowdlerizing Typee in a revised American edition (deleting the offensive Appendix, for instance) and persisting in his offense thereafter through a more murky, innuendo-laden style. I like to imagine Melville, even when dutifully applying the razor to the text of Typee, trying at the same time to bump the limit of what he could get away with. For instance, from the chapter on "Religion in Polynesia" he cut the last paragraph, which pretends to view the Typees "as a back-slidden generation" that "require a spiritual revival" - I trust because he thought that the sudden donning of the evangelical persona would be considered a too transparent reductio ad absurdum. (Compare the delightful parody of fundamentalist exegesis in the "Jonah Historically Regarded" chapter of Moby-Dick.) But he let stand a slightly more oblique earlier passage on the practice of ritualistic idol-mocking, which portrays the Typees tongue-in-cheek as a species of Yankee Congregational rabble:

The "independent electors" of the valley were not to be brow-beaten by chiefs, priests, idols, or devils. As for the luckless idols, they received more hard knocks than supplications. I do not wonder that some of them looked so grim, and stood so bolt upright as if fearful of looking to the right or the left lest they should give any one offence. The fact is, they had to carry themselves "pretty straight," or suffer the consequences. Their worshippers were such a precious set of fickle-minded and irreverent heathens that there was no telling when they might topple one of them over. ${ }^{13}$

Perhaps Melville thought the passage had enough protective coloring to obscure the parallel that his Yankeeisms drive home: that this could almost as easily be a satire on religious and social anarchy in the burnedover district of upper New York State, where evangelical ferment was at its height in Melville's youth, as a wide-eyed account of barbarous prac- 
tices in the South Seas. Considering the book as directed at a British readership, we can imagine this stylization one way-as designed to promote the illusion of the authenticity of the Yankee persona; in an American context, especially that of the revised edition, it makes equal sense to read Melville as trying to insinuate something about the absurdity of religious excess.

The publication history of Typee, then, shows Melville actively seeking to conciliate his respective British and American audiences while maintaining a kind of independence via obliquity or insinuation. In the long run, his binocular vision of the two audiences was clearly one source, though of course hardly the only one, of the nuanced convolution that marks his later fiction. Take, for instance, this footnote from White-Jacket on the subject of (interestingly) impressment. In the American edition, the note climaxes with a patriotic outburst: "These things should be known; for in case the English government . . . should again resort to indiscriminate impressment . . . it is well that both Englishmen and Americans, that all the world be prepared to put down an iniquity outrageous and insulting to God and man." But in the English edition this is prefixed by one disclaimer ("It is not intended to revive old feuds") and suffixed by another ("It is hardly to be anticipated" that an institution would ever be revived that "must surely seem iniquitous to the great body of Englishmen"). ${ }^{14}$ The result is an intricate piece of have-your-cake-and-eat-it-tooism, a warmup for the rhetorical tackings back and forth in Moby-Dick, Pierre, and The Confidence-Man.

Of course this note is a minor instance. A much more significant one is the plot of Redburn, the novel immediately preceding White-Jacket. The dual audience phenomenon provides us with a key to achieving a juster respect for the complexity of thinking that underlay this pot-boiler-if not for the finished product. One of Redburn's obvious "failures," yet a very provocative one, is the introduction in the last third of the book of Harry Bolton, the young English gentleman who becomes friends with Redburn and ships back to America with him after they take their abortive trip to London. Bolton has often been thought of as a flimsy, anti-climactic piece of cardboard-and so he is. Yet he is important as Redburn's double - another gentry-class nautical greenhorn who has to have the well-bredness beaten out of him in order to make it as a sailor and ultimately also as an American. As such, Bolton reruns the initiation 
theme in British guise and thus at least begins to become the protagonist in a subplot that might answer the vicarious needs of the British implied reader as Redburn does the American (in Melville's imagination of both, of course).

From this standpoint, the problem with the Bolton subplot is not that it is a belated tack-on, but rather that it isn't developed enough to become symmetrical with the main plot. Bolton remains an outsized episode in Redburn's series of experiences. Yet that too is important, indeed much more deeply so, in that the affair with Bolton both reenacts and displays the quixoticism of Redburn's attempt to decolonize himself, to shake off the inbred genteel Anglophilia that initially makes him a maladroit sailor and leads to a pathetically naive pilgrimage in his father's footsteps through Liverpool with the aid of an ancient guidebook brought from home. The guidebook episode is one of Melville's most inventive portrayals of intellectual colonization, in both familial and national senses. The map's gross inaccuracy and Redburn's brush with urban slums begin to awaken him mentally, but Harry Bolton is important in maturing him further, first by proving an initially attractive but then disillusioning image of English gentlemanliness and second through Redburn's sense of the contrast between Bolton's utter incompetence at sea and his own comparative seasoning. Yet Redburn is never emancipated. The point is that the narrative is about a decolonization process that never ends; the book concludes by focusing on Bolton more than on Redburn. It is by no means clear that Redburn has exorcised the Bolton within himself; on the contrary, it proves easier for him to exorcise the fearful Jackson (Bolton's opposite, the demotic tyrant) than the friendlier but more persistently demanding Bolton. Even as the presumably older and wiser narrator, Redburn continues to play the sentimental naif, albeit on a slightly more enlightened plane of cognizance. ${ }^{15}$

The putative double audience awareness in Redburn, assuming I am right in inferring it, is surely connected with the pursuit of the decolonization narrative in Redburn, given that the motif of partial but incomplete disengagement from Anglocentrism operates at both rhetorical levels (the level of address to readers and the level of narrative point of view). But to explain the latter solely in terms of the former, to attribute Melville's tailoring of plot and character solely to his strategic accommoda- 
tion to a bicontinental readership, would be thickheaded. Melville's lifeexperiences as world traveler and amateur comparative anthropologist might in themselves have been enough to make him deeply skeptical of, if not downright hostile to (despite his occasional young America-style setpieces), any attempt at descrying a clean distinction between old and new worlds. It is notable in this regard that Melville's most acidulous deflations of American claims of sociocultural difference and superiority occurred in magazine pieces of the 1850s directed at a cisatlantic rather than international market. In "Benito Cereno," for example, Melville arranged the antithesis between Delano and Benito as a pseudo-polarity so that the Yankee captain could not be exculpated from the racism, authoritarianism, and moral imbecility of his Hispanic (and by implication also Southern) counterparts. As in Moby-Dick, Melville tried to puncture democratic complacency by establishing a continuum between European imperialism and Yankee enterprise. But the Melville work most explicitly about postcolonialism is Israel Potter (serialized in Putnam's), whose protagonist finds himself ironically trapped in Britain for 40 years after American independence.

The Treaty of Versailles certainly did not free this American Israel, who languished in the captivity of London impoverishment until after the second war of independence. Israel Potter raises the question of whether American independence means anything for the average American. To the extent that Israel is symbolically a kind of everyman, then the answer is clearly no. For him at any rate, republican institutions prove dysfunctional, and his errand into the wilderness of the London slums (a metaphor developed with grim gusto) leads to a greater privation than that from which his forefathers came, despite all his Yankee ingenuity. In this reading of the text, of course, England isn't literally England, not just England anyhow, but alternatively or in addition a displaced version of the laissez-faire economics on which America itself is built.

Melville helps establish this equivalence by a series of revisions of his source text, the Life and Remarkable Adventures of Israel Potter. He doctors his portraits of John Paul Jones and Benjamin Franklin to emphasize the megalomania and decadence of Jones (who at one point wishes he were a czar) and the courtierish duplicity of Franklin. The original Israel insists that if "that great and good man" Benjamin Franklin were still alive, "I should not have petitioned my country in vain." In Melville, it immediately becomes clear that bland, calculating Franklin would have 
made no effort to help Israel; in fact he intimidates him into giving back the quarter he starts to lend him. Here and throughout, Melville makes light of the original narrative's dogged patriotism. The process starts with Melville's first use of his source, in chapter two: "It appears," says the narrator, that Israel "began his wanderings very early; moreover, that ere, on just principles throwing off the yoke of his king, Israel, on equally excusable grounds, emancipated himself from his sire"-who had forbidden his love-match. Linking these two items together as "equally excusable" rebellions of course reduces patriotism to parody. Later on, after reporting Israel's encounter with King George, the narrator laughs at Israel for being so impressed by the king's magnanimity: "had it not been for the peculiar disinterested fidelity of our adventurer's patriotism, he would have soon sported the red coat." 16 This rather dampens the impression of Israel's Yankee staunchness. In the next episode, when Israel meets up with the pro-American underground, Melville replaces the original scene of high patriotic drama with a scene in which three wily bantering gentlemen ply Israel with drink to soften him up for an errand he doesn't understand. And so on. The cumulative effect of these alterations is to turn Israel into a comic-pathetic shuttlecock bounding back and forth between Tweedledum and Tweedledee-with the main line of division between good and bad being not ideological but economicand to replace a narrative that loudly declares allegiance to America with an ironic meditation on the pseudo-polarity between republican freedom and the imperial yoke, exposing the quixotic, delusional character of the cultural nationalism that the historic Israel and his editor employ as a strategy of justification. This isn't to say that the Melvillian narrator lacks sympathy for Israel, any more than the narrator of Billy Budd lacks sympathy for Billy Budd, only that in each case Melville sees to it that vernacular republicanism gets upstaged by a skeptical, detached narrative voice.

Melville's astringency toward republican economic and political institutions in the work of the 1850 s that followed the overheated intensity and unsuccess of Pierre (1852) expresses another characteristic postcolonial motif: disillusionment at the incompletion of the social changes that ought to have followed from the political revolution. Indeed, the Englishlanguage inventor of this motif was the first major Anglophone writer to witness a revolution "completing" itself-John Milton, whose ironic sonnet "On the new forces of Conscience under the Long Parliament" charged that "new Presbyter is but Old Priest writ large." ${ }^{17}$ Ngugi's Petals 
of Blood, quoted earlier, pursues this theme on a grander scale, anatomizing the reinvention of structures of domination by postindependence entrepreneurialism. From the standpoint of Melville and many other Northern liberal writers following the Compromise of 1850, the American regime at mid-century looked, at worst, as retrograde as the Kenya of Daniel arap Moi does to Ngugi. Not that the disaffection of Melville's later fiction can be traced to any specific political event. The sectional crises of the 1840s and 1850s may suffice to explain the political disaffections of Stowe's Uncle Tom's Cabin, Emerson's addresses on the Fugitive Slave Law, or Thoreau's "Slavery in Massachusetts," but the disaffections of Moby-Dick, "Bartleby," "Benito," and Israel Potter express a more comprehensive disillusionment with republican premises reflective on the one hand of a vision of human corruptibility at once more broadly Euroamerican and more idiosyncratically personal and on the other of the entrapment of the individual within oppressive political and/or economic orders by no means peculiar to America. A closer African parallel than Ngugi, closer because more abstract, would be the satire of neocolonial royalism in Wole Soyinka's writings about African strongmen, such as Death and the King's Horseman, Opera Wonosi, and A Play of Giants. In these works particular instances are treated as type cases with a stylized intensity that seems to have its origins not just in the immediate contexts but in a magisterial vision of historical and even cosmic irony, surcharged by classical, Brechtian, and absurdist intertextuality. Soyinka's repeated exposures of the abuse of power recalls Melville's repeated commentary on the incongruity of monarchical codes of shipboard discipline persisting in a republic. White-Jacket is especially eloquent on this score, indicting the American Articles of War as "an importation from abroad, even from Britain, whose laws we Americans hurled off as tyrannical, and yet retained the most tyrannical of all." 18

No less significant for Melville than the bare injustice of shipboard imperialism were the psychological consequences thereof, the venality, emasculation, and cruelty that it can mask and produce. Yet equally compelling for us as readers is how, notwithstanding, Melville's texts reproduce a version of that hierarchicalism at the level of narrative consciousness. In White-Jacket, for instance, the idealized "ordinary" seaman is Jack Chase, a Briton (itself an advantage?) whose suavity and command of literary quotations make him a persuasive intercessor with the captain and (given that he is also a darned good fellow) the cynosure of the crew as well. The combination of these traits is what makes him a fit friend for 
the antiauthoritarian but also fastidious, effete White-Jacket. One quickly infers from this that the text has sought to create as a counterpoint to the titled officers not a direct opposite but a "natural aristocrat" who functions as more of an aristocrat than the text intends. A similar ambiguity invests Ishmael's bond to Ahab in Moby-Dick. More like Starbuck than he acknowledges, Ishmael obeys, rebelling, alternately critical of and fascinated by Ahab. Ishmael's notorious "disappearance" in the latter stages of the text could be read as a consequence of the text's investment in Ishmael's fascination, in that it permits-just as Ishmael has previously permitted-Ahabian power to dominate for the nonce over Ishmaelish reserve. The vision of Ahab as a latter-day Lear or Macbeth-or, for that matter, as a latter-day Ahab, a grand ungodly neo-biblical hero-villainthreatens to eclipse the "democratic" critique of Ahab as an abuser of authority.

Melville's practice of muddying the moral polarity of the monarchy/ democracy antithesis seems to have arisen from a combination of usurpation by his literary models (here one recalls Whitman's deduction from Shakespeare's greatness - that his imagination was tied to the feudal system) and conscious intent to rise to some meta-position from which "opposite" alternatives appear as mirror-images of insufficiency. This latter intention, which regulates the narrative angle in Billy Budd, Melville seems to have been consciously reaching after as early as Mardi, his third novel and the first work to anticipate closely his mature style. The primary sign of this is Mardi's appropriation of the convention of reverse orientalism originally pioneered in the eighteenth century by Montesquieu's Persian Letters - the imagination of how Western society would look to an oriental traveler - as the narrator-protagonist Taji is escorted by King Media and several of his courtiers through all the realms of Mardi. During the latter stages of this tour, the voyagers visit England (Dominora) and the United States (Vivenza), passing by Europe (Porpheero), which is caught in the Revolutions of 1848. Melville's Americanness of perspective is evident from such signs as the decision to give Vivenza more than equal time. But the narrative form of this progress establishes an equivalence between the cultures of imperialist Britain and bumptious postcolonial America as social pathologies witnessed from an Olympian point of view. Indeed, the text suggests specific parallels between imperialism and American-style democracy in its satire on American slavery and expansionist designs on Mexico and Cuba. That Melville was well aware of the scandalousness of this analogizing is clear from the fact 
it is broached most explicitly in a mysterious scroll read by the infuriated Vivenzans that the text strongly hints was surreptitiously posted by one of the voyagers, perhaps either Media or the sage Babbalanja. ${ }^{19}$ This is the only portion of the whole vast, sprawling novel that cannot be attributed to any specific voice.

Melville did not always feel it necessary to handle the subject so delicately. In the sixty-fourth chapter of White-Jacket, for instance, the Neversink prepares to race a British frigate. The narrator disingenuously fans the fires of partisan enthusiasm by informing us that nearby lay a "British" ship that had been captured from the American navy in the War of 1812: "Think of it, my gallant countrymen, one and all, down the seacoast and along the endless banks of the Ohio and Columbia-think of the twinges we sea-patriots must have felt to behold the live-oak of the Floridas and the pines of green Maine built into the oaken walls of Old England!" But he abruptly deflates his mounting drama of cross-national rivalry with an aside about a Sioux Indian he once saw "exhibiting on the back of his blanket a crowd of human hands"-the record of his trophies. The moral is obvious: "what is the American frigate Macedonian, or the English frigate President [each captured in the past war by the other side], but as two bloody red hands painted on this poor savage's blanket?" 20 The ensuing race is chronicled with an odd mixture of narrative gusto and ironic detachment from the event as a ludicrous exercise in patriotic overcompensation.

Altogether, what is perhaps most characteristic of Melville's use of literal and symbolic contrasts between "English" or "European" and "American" positions is their instability - their occasional nature, their shiftingness, their discontinuities, and at times their sheer adventitiousness and fortuity. (The Dominora-Vivenza sequence in Mardi reads suspiciously like a belated tack-on, for example.) As we try to understand what to make of all this, it is well to bear in mind an important controversy in (post)colonial studies, brought into focus by the much-publicized mid-1980s exchange between Fredric Jameson and Aijaz Ahmad concerning the characteristic preoccupations of third-world literature. Jameson claimed that "all thirdworld texts are necessarily, I want to argue, allegorical, and in a very specific way: they are to be read as what I will call national allegories." Ahmad objected to this as an intolerably totalizing diagnosis, denying heterogeneity of all antecedence, purpose, and result, trapping "us" in 
"the same allegory, the nationalist farce, re-written, over and over again, until the end of time." Instantiating the case of Urdu, his own literary culture, Ahmad went on to state that before Pakistan's independence, "the theme of anti-colonialism is woven into" Urdu fiction "but never in an exclusive or even dominant emphasis" and that the subsequent prominence of nationality as a theme has to do with the peculiar circumstances of Pakistani independence (involving partition, traumatic mass migration, and a bloodbath that still continues). ${ }^{21}$ This controversy sheds analogical light on the American case. Jameson here might stand for the practice, long ingrained among Americanists, of imagining American literary development in terms of cultural differentiation: the discovery of a native poetic language and form (e.g., Whitmanian catalogues), the development of a repertoire of native or adopted genres (e.g., the captivity, the slave narrative, the jeremiad, the wilderness romance), the invention of an American mythography (e.g., American Adamism). Ahmad here stands for the insufficiency of any theory of a nationalist agenda. Both oversimplify (Jameson must homogenize the third world; Ahmad must minimize the extent to which his case study provides qualified evidence supporting Jameson); both are, up to a point, right. My essay has on the whole been more Jamesonian than not, even though it has run counter to the main drift of Americanist work in stressing the impossibility of making a clean break from Europe in literary practice. To make this case, however, it has had to risk reducing American letters to still another "main theme." So the Ahmadian counter-truth ought now be insisted upon with full force: the "main theme" (the preoccupation with AngloAmerican imbrication and/or juxtaposition at any level) does not finally tell us more than a limited amount about Melville's work, although what it does tell us is helpful, indeed decisive in its own way.

An example that will help to bring this point into sharper focus is an amusing episode near the end of Melville's second novel, Omoo, just before the narrator's departure from Tahiti on the American whaler Leviathan. The narrator is put at great pains to convince the captain that he is, in fact, a Yankee. This he must do in order to get the suspicious skipper to agree to sign him on as a member of the crew. But when first he approaches the captain, together with his Australian shipmate and traveling companion Doctor Long Ghost, the captain refuses to believe that our hero is not himself Australian, a species "in excessively bad odor" throughout the Pacific. ${ }^{22}$ This comical episode, showing that you sometimes need to put on an act in order to convince people that you are 
what you are, suggests at once the author-narrator's deracination and his early awareness of the theatricality of any discourse of national identity. Although the episode describes the persona only qua experiencer, the lesson is clearly also one that Melville had to relearn in his capacity as author, for at least two purposes: first in order to create a beachcomber persona that would negotiate the borderland between "civilization" and "savagery" in a way both cogent and pleasing to Anglo-American readers, and second in order to respond to the pressure upon him to engraft the unvarnished narrative of an ordinary Yankee upon what Melvillians have liked to call "the complex psychology of a failed patrician." ${ }^{23}$ Thus Melville's renditions of cultural nationalism are typically short-run, qualified, and self-conscious. No better example can be found than the peroration to the first "Knights and Squires" chapter of Moby-Dick, where Ishmael calls upon the "great democratic God" to bear him out as he seeks to "ascribe high qualities" "to meanest mariners, and renegades and castaways." F. O. Matthiessen made this passage canonical when, in American Renaissance, he held it up as the example par excellence of Melville's democratization of Shakespearean rhetoric, characterizing it as a "fullvoiced affirmation of democratic dignity." ${ }^{24}$ Matthiessen was right that the passage masterfully interweaves colloquial and high cultural rhetoric, but he erred in overlooking its studiously bombastical nature, which telegraphs to the urbane reader that this noisy apotheosis of the common man is a playful extravagance, a mask for the occasion.

Matthiessen, like Jameson, and like most of us who are Matthiessen's Americanist successors today, strives to identify distinctively national subtexts and national styles of expression in our "classic" authors. The New Historicist practice of identifying American slavery in general and the Compromise of 1850 in particular as master-referents of classic American literature (equally important in their absence as well as their presence) is the most striking recent case of the quest for the national subtext. ${ }^{25}$ I certainly do not want to discredit this project (and others like it), but merely to worry about the blindness that seems inevitably to accompany its insight: namely, the taking for granted that the American 1850 is a more important litmus test of the social themes of midnineteenth century American literature than, say, the growth of the international market economy, the impact of European socialist thinking, or the European revolutions of $1848 .{ }^{26} \mathrm{My}$ view is that the 1850 test is a test that Melville, for one, cannot be expected to pass without very significant qualifications, any more than Urdu literature can pass the national alle- 


\section{American Literature}

gory test imposed by Jameson. In Mardi, for example, Melville indeed wishes to address the problem of American slavery as a national scandal, but not as "an exclusive or even dominant emphasis." This preoccupation with the great national evil, as we have seen, is contained within an internationalist framework of vision whereby Vivenza and Dominora look like counterparts; and this whole section of the text is a relatively brief island in the vast ocean of quest romance whose most salient literary pre-text is Shelley's Alastor.

To be sure, some of Melville's later writings fit much better into a theory of his career as developing some kind of American project. Taken in isolation from the rest of his canon, works like "Bartleby," Pierre, and especially The Confidence-Man can be invoked to make the case that Melville's attention turned increasingly toward anatomies of American social issues and toward the question of what sort of expression, artistic or otherwise, is possible within the context of American institutions. White-Jacket and Moby-Dick, read as critiques of the American navy and the whaling industry respectively, might be seen as transitional works leading Melville toward predominantly cisatlantic preoccupations in the later works just mentioned. The insufficiency of this view of Melville, however, if it is not already clear from the foregoing, becomes immediately so when we reckon with his last monumental work-Clarel (1876), Melville's 500-page four-part autobiographically-based narrative poem focusing on the impressions of a group of more-or-less pilgrims as they visit and reflect upon holy sites of Palestine.

This is the great white elephant, the great unread, not only among the ambitious works of the Melville canon but among all the major works of all the canonical nineteenth-century English-language authors. Melville's achievement is often generalized without reference to it. Yet this religious epic - which, despite its repellently relentless iambic tetrameter couplet prosody, deserves honor as the second most learned, intricate, and profoundly intellected work Melville wrote-helps greatly to put into perspective his achievement as an American writer. Its basic plot device, which Clarel helps us to recognize was Melville's staple device almost from start to finish, is to juxtapose a medley of culturally disparate individuals within a closed setting suggesting a world in microcosm. America is disproportionately represented, most of the featured pilgrims being American expatriates or wanderers, and American history (e.g., the Civil War) is often brought up, but seemingly neither in a spirit of postcolonial anxiety nor of nationalist assertion. These have yielded to a detachedly 
anthropological perspective from which vantage point it looks, as the putatively most Melvillian character puts it, as if

... Our New World bold

Had fain improved upon the Old;

But the hemispheres are counterparts. (IV.v.62-64)

America has "come of age"; it no longer worries about the shadow of Europe; but its maturity is nothing to be proud of, for it merely establishes America on the same footing. In one exchange, surrounded by a knot of irresolute skeptics and malcontents from the Americas, the one European character (a doggedly optimistic Anglican priest) points out the irony that "I of the Old World, all alone" maintain "hope and ground for cheer / "Gainst ye, the offspring of the New" (IV.xix.103-05). A thrice-marginalized Civil War veteran (Confederate, Catholic, part Indian) retorts:

Old World? If age's test

Be this-advanced experience,

Then in the truer moral sense,

Ours is the Old World. You, at best,

In dreams of your advanced Reform,

Adopt the cast skin of our worm. (11. 108-13)

This might easily have been a nationalist statement-as in later years it was for Gertrude Stein. Instead, it reflects a perspective from which particular pilgrims' points of national origin are much less material than their philosophical standpoints. Even Melville's rhetoric and prosody do this: he avoids vernacularization to the extent possible and stiffens his verse into a rough archaic dignity not identifiably American or even modern. Clarel's presumption concerning the national project-not the American alone but all forms of modern nationalism - seems to be that the riddle of identity, in all the ways that term can be construed, leads back to the ancient world, which supplies a venue for examining the wreckage of latter-day Levantine and Euro-American civilization as interchangeable symptoms of the bankruptcy of nineteenth-century thought. Thus the case of Nathan, the Illinoisan of Puritan stock who converts to Judaism and becomes a Zionist, is almost interchangeable with that of the Swede Mortmain, whose disillusionment with the revolution of 1848 turns his utopianism into cosmic pessimism. Thus the motif of expatriation, which virtually all the pilgrims share, does not have the same social valence 
that it had for Redburn or Israel Potter, or even for the noted American literary expatriates from Irving to Henry James or Gertrude Stein. Expatriation is neither an instrument of cultural awakening nor a means of comparing national difference so much as a symptom of the pathology of national identity as such.

Clarel prepares us to return to our starting point-Melville's next and final masterpiece, Billy Budd. The obliquity with which Billy Budd invokes one of the most vexing stigmata of American postcolonialism would not have been possible without the detached vision of which Melville shows himself to be capable in Clarel, which develops the theme of interchangeable national narratives more fully than any other Melvillian work. The story of the consequences of impressment, for all Melville cares, can just as easily play itself out in the form of a British episode in the aftermath of the French Revolution as in the form of an Anglo-American confrontation during the early national period. The name of Billy Budd's first ship, the Rights of Man, can just as easily refer to the French avatar of Thomas Paine as to the American.

I must therefore refine my initial statement about Billy Budd as a postcolonial text in light of the path we have traversed. Reviewing Melville's career, we can see his voyage-plots from Typee to Clarel as manifesting a prolonged struggle over the business of writing an American narrative in any or all these senses-over whom he was writing for, over what his subjects would be, over what his models would be, over where his social values lay. Out of this struggle, Melville constructed personae that were at most self-consciously and fitfully American. Any visions or aspirations he harbored to become an American author or forge an American literature were held in check at the start by his pragmatic accommodation to international marketplace constraints. When he began to assert himself as an independent, "serious" artist in Mardi, the American project generally remained subordinate to comparative anthropology and metaphysical questing; modern political history took precedence over American history, world religion over Puritanism. The origins of this cosmopolitanism lay in his postcolonial anxiety to think transcontinentally, but it fully matured only after and partially as a result of going through a comparatively "American" phase at mid-career, during which Melville more directly confronted the parochialism of national narratives and of national styles of expression. The way Billy Budd engages the subject of impressment shows that. Melville perhaps never arrived at the zero degree of intellectual colonization (who ever does?), but he achieved a degree of magisterial casualness about an American subject that bespoke a secu- 
rity of conviction that it belonged not alone to the province of American literature but to world literature.

In conclusion, I should like to comment briefly on some of the broader inferences that seem to follow from my account of Melville's career. My myth of Melville's trajectory suggests the need for Americanists to think about the history of "American" writing in more complexly transnational terms than heretofore-to reflect on how other cases of postcolonial literary emergence might bear on the American; to foreground an awareness that the whole notion of emerging national literary autonomy is a totalizing fiction, a critical construct potentially as provincial in its own way as the state of intellectual colonization from which the supposed autonomy emerged; and to presume that "American" authors will be fitful and inconsistent in the degree to which they embrace "native" aesthetic norms, themes, subjects. Now that the dream of nationalism has been thoroughly demystified by Benedict Anderson and others who have revealed its status as a species of social fiction, ${ }^{27}$ the approach to American literature as a species of distinctive national narrative ought also to be interrogated more strenuously as a myth that American authors broached and American critics formalized in a much more complicated transnational historical matrix that included contrary evidence and competing possibilities. This is by no means to deny all evidential basis to the myth, nor to deny its psychohistorical necessity. (Since language doesn't really differentiate American literature, the need to assert cultural autonomy becomes all the greater-another common ground with other postcolonial literatures written in European languages.) But at least we also need to become more cognizant of the degree to which our instruments for measuring the Americanness of American literature are instruments of our desire.

Harvard University

\section{Notes}

Earlier versions of this essay were delivered as lectures at the Melville Society Centennial Conference (Pittsfield, Mass., May 1991) and the Wisconsin Melville Centennial (Madison, October 1991). I am grateful for comments and suggestions received on both occasions.

1 R.W. B. Lewis, The American Adam (Chicago: Univ. of Chicago Press, 1955), 146-52.

2 In The Poems of Andrew Marvell, ed. Hugh MacDonald (Cambridge: Harvard Univ. Press, 1952), 105, these first four lines of stanza 91 italicize "Domestick Heaven," "Discipline," "Fairfax," and "Vere," with other orthographical 
234 American Literature

changes indicated here; otherwise, Melville's quotation in section 6 of Billy Budd is identical.

3 Raymond Williams, The Country and the City (New York: Oxford Univ. Press, 1973), 57.

4 The subject of American literature's slow and conflicted movement toward cultural autonomy has long been a topic of research. Two excellent recent studies in this tradition are Jeffrey Rubin-Dorsky, Adrift in the Old World: The Psychological Pilgrimage of Washington Irving (Chicago: Univ. of Chicago Press, 1988); and Robert Lawson-Peebles, Landscape and Written Expression in Revolutionary America (New York: Cambridge Univ. Press, 1988). The differences between this tradition of inquiry and mine in this article are chiefly that I see the literary nationalist project as a more fitful, incomplete, and ultimately secondary affair, and that I am inclined to see it comparatively, in relation to other cases of literary emergence in former colonies. Hence my use of "postcolonial." I do not mean to imply a simple equation between, say, a settler culture like that of Anglo-America and an indigenous culture like those of Nigeria or the Indian subcontinent, nor do I mean to suggest that, say, the United States and Australia offer interchangeable literary histories. I would simply argue that such cases can be mutually illuminating. For a preliminary justification of this, see Bill Ashcroft, Gareth Griffiths, and Helen Tiffin, The Empire Writes Back: Theory and Practice in Post-Colonial Literatures (New York: Routledge, 1989); for a more sophisticated application to a single genre, see Homi K. Bhabha, ed., Nation and Narration (New York: Routledge, 1990).

5 Herman Melville, Journals, ed. Howard C. Horsford and Lynn Horth (Evanston and Chicago: Northwestern University Press and The Newberry Library, 1989), 46-47, 23. Here are some other examples. Remembering a ride about London: "Here the poet Thompson (sic) dwelt. I was on top of the coach. Pope lived near here, at Twickenham" (16). On dining at Elm Court, Temple: "A set of fine fellows indeed. It recalled poor Lamb's 'Old Benchers'” (44). Melville's perception of a Europe resonant with associations rendered familiar yet exotic through previous reading is very much in the mold of the nineteenth-century sentimental traveler.

6 See particularly the burst of literary nationalism following Melville's comparison of Hawthorne to Shakespeare in "Hawthorne and His Mosses," in which Melville exclaims, "let America first praise mediocrity even, in her own children, before she praises . . . the best excellence in the children of any other land." Moby-Dick, ed. Harrison Hayford and Hershel Parker (New York: Norton, 1967), 544. I argue below that this kind of rhetoric is an occasional motif in Melville, not a dominant or unqualified note. For an important statement that takes the case against defining American literature in terms of its Americanness a bit too far in the right direction, see William Spengemann, A Mirror for Americanists (Hanover: Univ. Press of New England, 1989). 
7 Phanuel Egejuru, Towards African Literary Independence: A Dialogue with Contemporary African Writers (Westport, Conn.: Greenwood, 1980), 9. Cf. Timothy Brennan's more tempered observation, in a recent essay on Salman Rushdie, that the last several decades have witnessed "a trend of cosmopolitan commentators on the Third World, who offer an inside view of formerly submerged peoples for target reading publics in Europe and North America in novels that comply with metropolitan literary tastes" ("The National Longing for Form," in Nation and Narration, ed. Bhabha, 63). The question of the audience of African literature is discussed in broader terms in Rand Bishop, African Literature, African Critics: The Forming of Critical Standards, 19471966 (New York: Greenwood, 1988), 47-58. With regard to the analogy to American antebellum writing, see also my discussion of the two audience issue in "American Literary Emergence as a Postcolonial Phenomenon," forthcoming in American Literary History, 1992.

8 Ngugi wa Thiong'o, Petals of Blood (New York: Dutton, 1978), 67.

9 See, for example, Stephen Railton's recent study, Authorship and Audience: Literary Performance in the American Renaissance (Princeton: Princeton Univ. Press, 1991), whose Melville chapter represents him as exclusively preoccupied with his relations to the American reading public even as it shows cognizance of his international publishing ventures (152-89). This assumption works better for some works (e.g., Pierre) than for others (e.g., Typee). Our vision of Melville may become more usefully complicated if we impute to him a multiple and shifting notion of the implied reader.

10 Washington Irving, "English Writers on America," The Sketch-Book, in History, Tales and Sketches, ed. James Tuttleton (New York: Library of America, 1983), 786-94.

11 Melville in the South Seas (New York: Columbia Univ. Press, 1939), 336.

12 Herman Melville, Typee, ed. Harrison Hayford, Hershel Parker, and G. Thomas Tanselle (Evanston and Chicago: Northwestern Univ. Press and The Newberry Library, 1968), 293-94; Hugh Hetherington, Melville's Reviewers (Chapel Hill: Univ. of North Carolina Press, 1961), 47.

13 Typee, 177-78. My notion of Melville's approach to the author-reader relation is obviously somewhat at variance, although not so much as it might seem, with Wai-chee Dimock's eloquent "imperial" reading in Empire for Liberty (Princeton: Princeton Univ. Press, 1989). With regard to Melville's pipedream of an ideal understanding reader for Mardi, Dimock remarks that this was "a fiction created by an imperial self, a self that annihilates what it refuses to imagine and appropriates what it projects as its own" (75). I argue for a more receptive, pragmatic, accommodationist Melville on the basis of his acceptance of a degree of enforced obliquity and censorship (both in the composition and the copyediting stages), and on the basis of his willingness to alternate between "serious" and "light" work until nearly the end of his active professional career as a novelist. But Dimock is surely correct in positing a willful Melville, whose energy I see as driving the passage just 
discussed, whether or not this energy can be diagnosed as a phenomenon of the American expansionist moment (Dimock, 10).

14 White-Jacket, ed. Harrison Hayford, Hershel Parker, and G. Thomas Tanselle (Evanston and Chicago: Northwestern Univ. Press and The Newberry Library, 1970), 381.

15 In other words, I question the theory that there is a stable ironic distance between the narrative voice and the figure of the young Redburn, though I would agree that they are not the same. This means that I would posit another distinction between narrative voice and implied author.

16 Israel Potter, ed. Harrison Hayford, Hershel Parker, and G. Thomas Tanselle (Evanston and Chicago: Northwestern Univ. Press and The Newberry Library, 1970), 381.

17 The Poetical Works of John Milton, ed. Helen Darbishire (New York: Oxford Univ. Press, 1958), 439.

18 White-Jacket, 297.

19 Mardi, ed. Harrison Hayford, Hershel Parker, and G. Thomas Tanselle (Evanston and Chicago: Northwestern Univ. Press and The Newberry Library, 1970), 524-30.

20 White-Jacket, 266, 267.

21 Fredric Jameson, "Third-World Literature in the Era of Multinational Capitalism," Social Text 15 (1986): 69; Aijaz Ahmad, “Jameson's Rhetoric of Otherness and the "National Allegory," Social Text 17 (1987): 9, 21.

22 Omoo, ed. Harrison Hayford, Hershel Parker, and G. Thomas Tanselle (Evanston and Chicago: Northwestern Univ. Press and The Newberry Library, 1968), 313.

23 T. Walter Herbert Jr., Marquesan Encounters (Cambridge: Harvard Univ. Press, 1980), 155. Herbert here recalls Newton Arvin, Herman Melville (New York: Houghton, 1950), 23.

24 Moby-Dick, ed. Harrison Hayford, Hershel Parker, and G. Thomas Tanselle (Evanston and Chicago: Northwestern Univ. Press and The Newberry Library, 1988), 117; F. O. Matthiessen, American Renaissance (New York: Oxford Univ. Press, 1941), 444-45.

25 For an example of this practice, see the essay that I would regard as the first work of important New Historicist exegesis in American Renaissance studies, Jonathan Arac, "The Politics of The Scarlet Letter," in Ideology and Classic American Literature, ed. Sacvan Bercovitch and Myra Jehlen (New York: Cambridge Univ. Press, 1986), 247-66. For a penetrating discussion of the significance of this move, see Philip Fisher's editorial Introduction to The New American Studies: Essays from "Representations" (Berkeley and Los Angeles: Univ. of California Press, 1992), xv-xviii.

26 For the impact of the latter on antebellum American writers, see especially Larry J. Reynolds, European Revolutions and the American Literary Renaissance (New Haven: Yale Univ. Press, 1988). Scholarly handling of international events of 1848 is a particularly interesting indicator of the rela- 
tive weight given by Americanist scholarship to cisatlantic and transatlantic reference. For example, Michael Rogin's Subversive Genealogies (New York: Knopf, 1983), a landmark study that helped redirect Melvillians to the study of his political context, clearly recognizes that this context has to be understood as transcontinental and that the Young America circle with which Melville was connected in the 1840s "borrowed its name from Mazzini's Young Italy" (71); but when it comes to textual analysis, it is "the American 1848" on which Rogin concentrates: e.g., "As the biblical Ahab seized Naboth's vineyard, so America engrossed half of Mexico" (126). For a recent Americanist reading of another major figure's career of the period that focuses more squarely on his bicontinental vision, particularly as regards the challenge of socialism, see Sacvan Bercovitch, "Emerson, Individualism, and the Ambiguities of Dissent," South Atlantic Quarterly 89 (1990): 62362. Rogin, Bercovitch, and Reynolds all exemplify, in increasing degrees, the attempt to reach beyond cisatlanticism and achieve an internationalized perspective on their American subjects commensurate with the subjects' own intellectual reach; but in order to do this they and all other Americanists must struggle, as Reynolds points out, against the "critical tradition in American studies" to emphasize "the national features of the literature it has treated, thus obscuring the substantial international influences" (xii).

27 Benedict Anderson, Imagined Communities: Reflections on the Origin and Spread of Nationalism (London: Verso, 1983), 28-37, develops the idea of novelistic form as a prototype for and influence upon the development of nationalism. Bhabha, "DissemiNation," Nation and Narration, 308-11, criticizes Anderson's model for being based on the assumption of novelistic realism, but Bhabha's skepticism is aimed at unsettling a too simple way of imagining national history as narrative; his collection actually furthers Anderson's goal of demystifying nationalism by recourse to the analogy of fiction. 